\title{
Diversity and spatial and temporal variation of benthic macroinvertebrates with respect to the trophic state of Lake Figueira in the South of Brazil
}

\author{
Diversidade e variação espacial e temporal de macroinvertebrados bentônicos \\ em relação ao estado trófico da lagoa da Figueira no Sul do Brasil
}

Fernanda Blauth de Lima, Alois Edward Schäfer and Rosane Maria Lanzer
Laboratório de Limnologia, Centro de Ciências Agrárias e Biológicas, Universidade de Caxias do Sul, CEP 95070-560, Caxias do Sul, RS, Brazil e-mail: nandalima85@gmail.com; aschafe1@ucs.br; rlanzer@ucs.br

\begin{abstract}
Benthic macroinvertebrates are widely used in evaluations of environmental impact and recommended in biomonitoring, but little used in Brazilian lentic environments. One of the main objectives has been to explain and predict the distribution of those species according to environmental characteristics. Thus, the study aims to characterize the predominant fauna of the Lake Figueira sediment and its relationship with organic matter and depth, analyzing seasonal variation in communities and aiming to select bioindicators of the trophic state. Sampling was carried out from January 2008 to January 2009, along the lagoon fetch, with an Ekmann-Birge dredge (area $225 \mathrm{~cm}^{2}$ ). Taxon richness was not significantly related with depth and organic matter content, but those variables were highly correlated $\left(r=0.962 ; r^{2}=0.926\right.$ and $\left.p<0.001\right)$. The constant oxygenation of the whole water column allows the occurrence of organisms, independent of depth and organic matter content. Chironomidae was the most abundant taxon and from the frequency of occurrence, abundance and clustering analysis it was possible to select Larsia sp., Goeldichironomus maculatus, Xenochironomus sp., Aedokritus sp. Cladopelma forcipis, Cryptochironomus brasiliensis, Nilothauma sp.1 and Caladomyia sp. C, Tanytarsus sp., Tanytarsus rhabdomantis and Chironomus gr. salinarius as potential indicators related with the spatiotemporal faunal distribution of Lake Figueira.
\end{abstract}

Keywords: benthos, chironomidae, coastal lagoon, monitoring.

Resumo: Macroinvertebrados bentônicos são amplamente utilizados nas avaliaçōes de impacto ambiental e recomendado em biomonitoramento, mas pouco utilizado em ambientes lênticos brasileiros. Um dos principais objetivos tem sido explicar e predizer a distribuição das espécies de acordo com as características ambientais. Assim, o estudo tem por objetivo caracterizar a fauna predominante do sedimento da Lagoa da Figueira e sua relaçâo com a matéria orgânica e profundidade, analisando as variaçóes sazonais nas comunidades e com o objetivo de selecionar bioindicadores do estado trófico. A amostragem foi realizada a partir de Janeiro 2008 a janeiro 2009, ao longo do fetch da lagoa, com uma draga Ekmann-Birge (área $225 \mathrm{~cm}^{2}$ ). Riqueza de táxon não foi significativamente relacionada com a profundidade e teor de matéria orgânica, mas essas variáveis foram altamente correlacionadas $\left(r=0,962, r^{2}=0,926\right.$ e $\left.p<0,001\right)$. A constante oxigenação de toda coluna de água possibilita a ocorrência dos organismos independente da profundidade e conteúdo de matéria orgânica. Chironomidae foi o táxon mais abundante e a partir da frequência de ocorrência, abundância e da análise de agrupamento foi possível selecionar Larsia sp., Goeldichironomus maculatus, Xenochironomus sp., Aedokritus sp., Cladopelma forcipis, Cryptochironomus brasiliensis, Nilothauma sp.1, Caladomyia sp. C, Tanytarsus sp., Tanytarsus rhabdomantis e Chironomus gr. salinarius como potenciais indicadores relacionados com a distribuição espaço-temporal da fauna da Lagoa da Figueira .

Palavras-chave: bentos, chironomidae, lagoa costeira, monitoramento. 


\section{Introduction}

The conservation of aquatic environments is of fundamental importance for sustainability of water resources. Environmental monitoring is indispensable for the analysis of the ecological status and degree of anthropic impact of those ecosystems, providing subsidies for the elaboration of management and conservation strategies (Fusari, 2006).

Ever since lakes begun to be studied as habitats, benthic organisms have been used as indicators of ecological or trophic status. Thienemann (1925; 1931) at the beginning of the XXth century was the pioneer in lake classification, using the presence or absence of different macroinvertebrate taxa in the sediment, as a criterion, differentiating oligotrophic lakes from eutrophic ones. Calling oligotrophic lakes "Tanytarsus lakes" and eutrophic lakes "Chironomus lakes". However only in recent years has this been emphasized in Brazil.

Guereschi and Melão (1997) define biomarkers, as organisms or communities that respond to environmental pollution, changing their vital functions. They may also be considered organisms or communities that react to those alterations providing information about the environmental situation.

Biomarkers have been widely used in the evaluation of impacts on ecosystems, reflecting the overall ecological integrity of ecosystems and their lasting environmental effects, whereas physicochemical methods only give instantaneous information.

Attempts have been made to understand the distribution patterns of aquatic communities in appropriate time scales in order to identify biotic diversity, in response to local factors and historical processes, that influence the occurrence and persistence of some species in a local habitat (Silva, 2010). Among those communities, the macroinvertebrates have been widely studied (Resh and Jackson, 1993). This interest is due, in part, to the recognition of the importance of this group for aquatic ecosystems, either by participating in the energy flow and nutrient cycling (Abílio et al., 2007) or in biomonitoring and environmental evaluation programs (Rosenberg and Resh, 1993; Wetzel, 2001; Garcia-Criado et al., 2005).

The distribution and diversity of benthic macroinvertebrates are influenced, directly, by the sediment structure and amount of organic debris and, indirectly, by modifications in the concentration of nutrients and modifications in primary productivity (Ward, 1992). Organic matter, deposited in the sediment constitutes an important habitat and source of food for the benthic macroinvertebrates. On the other hand, high levels may be harmful, leading to anoxic conditions in the sediment, reducing survival or even leading to mortality of organisms (Krull, 1970; Rodrigues and Hartz, 2001). Thus, the communities of benthic macroinvertebrates reflect the ecological conditions of the aquatic ecosystems they inhabit.

Eutrophication and/or organic enrichment of an aquatic system increases the density and/or biomass of some of the more tolerant taxonomic groups, such as Oligochaeta (Wiederholm, 1980), some Chironomidae larvae, especially Chironomus (Johnson et al., 1993), and decreases benthic species diversity (Barton and Metcalfe-Smith, 1992; Resh and Jackson, 1993), as a result of the disappearance of more sensitive species and the predominance of species tolerant to adverse conditions (Benke, 1984; Cairns Junior and Pratt 1993).

The coastal plain of Rio Grande do Sul (RS), southern Brazil has a large number of water bodies, which are mostly freshwater. The region has a unique coastal ecological system due to its dimension and the heterogeneity of its terrestrial and lentic habitats. The North Shore was the target of much research on vegetation, terrestrial fauna and its lagoons, while whereas the Central and South Shore lagoons have not been studied since the pioneer works of the eighties. The costal lagoon system where Lake Figueira is included originated by processes of transgression and regression of the ocean during the Holocene, about 5,100 years ago (Schwarzbold and Schäfer, 1984; Tomazelli and Villwock, 2005).

The use of benthic macroinvertebrates to characterize the ecological status of the coastal lagoons of Rio Grande do Sul began with Lanzer and Schäfer (1985; 1987; 1988), who determined the trophic state using the mollusc community in three common habitat types, along the coastal lagoon system.

Thus the study presents the composition of the benthic fauna, seasonal variation in the assemblage of benthic macroinvertebrates and its relationship with depth and content of organic matter of Lake Figueira sediment, subsidizing the future monitoring of this ecosystem, since this Lagoon is situated in the region of study of this research group, encompassing other coastal lagoons, monitored since 2008, allowing future comparisons. 


\section{Material and Methods}

\subsection{Study area}

Lake Figueira is situated in the municipality of Mostardas (UTM -X: 540676, Y:6603957), in the central coast, belonging to the Hydrographic Region of Rio Grande do Sul Coastal Basins (Figure 1A and $\mathrm{B}$ ). The climate in the region is of Cfa type (Kottek et al., 2006). The lagoon has an area of 8.2 $\mathrm{km}^{2}$ and its maximum depth is $11.1 \mathrm{~m}$, having a morphology with marked asymmetry (Schäfer et al.,
2009). The region is characterized by agricultural use, predominantly rice cultivation, cattle breeding and forestry (Rossato and Pinheiro Jr., 2009).

\subsection{Sediment collection}

The collections were carried out seasonally, between January 2008 and January 2009. Ten sampling points and their depth were determined by bathymetric profiles using an echobathymeter, taking into account different depth ranges, associated with GPS positions. The samples were
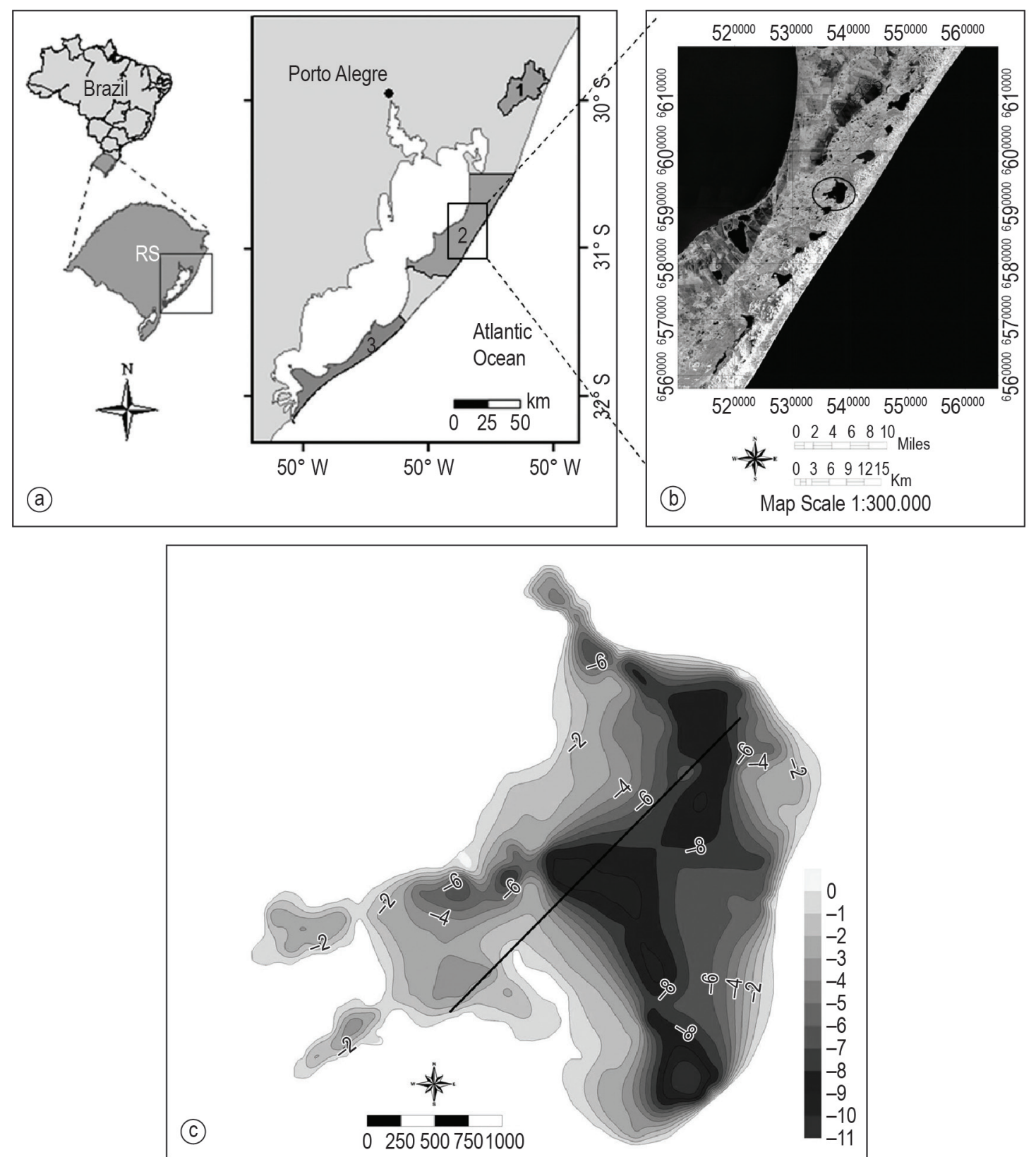

Figure 1. (A) Scope of the study areas of the research group in the municipalities of Osório, the North Coast (1) Mostardas (2) and São José do Norte (3), the East Coast of Rio Grande do Sul; (B) Lake Figueira (circle), municipality of Mostardas, central coast Rio Grande do Sul; (C) bathymetric map of Lake Figueira, with sampling points. 
made along a transect in the direction of the lagoon fetch, in other words, in the Northeast-Southeast direction, with spacing from one point to another of $4 \mathrm{~m}$ (Figure 1C).

The sediment was collected with an EkmannBirge dredge, with $225 \mathrm{~cm}^{2}$ area and 2.5 liter volume, with three replicas at each sampling point. The Ekmann-Birge dredge is suitable for bottoms with muddy or fine sediments, in deep zones (Merritt and Cummins, 1996; Merritt et al., 2005). In the laboratory the samples were dried in a kiln, at $60{ }^{\circ} \mathrm{C}$, for 72 hours. Then a subsample was removed weighing between $15 \mathrm{~g}$ and $40 \mathrm{~g}$. The determination of the amount of organic matter in the sediment was performed by loss by ignition. The subsamples were weighed in porcelain crucibles with a precision analytical balance and then burned in a muffle furnace, at $550{ }^{\circ} \mathrm{C}$, for 4 hours. The subsamples were weighed again, after ignition, and then, the content of organic matter of the sediment, in percentage, was measured.

The percentage of organic matter content of each sampling point was determined using the following equation (Equation 1):

$\mathrm{OM}=\frac{\mathrm{Iw}-\mathrm{Fw}}{\mathrm{Iw}} * 100$

where: $\mathrm{OM}=$ Sediment Organic Matter content (\%); Iw = Initial Weight of the sediment subsample; $\mathrm{Fw}=$ Final Weight after ignition .

\subsection{Benthic macroinvertebrates}

The collection of macroinvertebrates followed the same procedure as that of the sediment and was carried out immediately after the former. The sediment was fixed in buffered formaldehyde $4 \%$, and screened in laboratory with the help of a stereoscopic microscope Leica - MS5 and ZEISS - Stemi DV4. The organisms were preserved in glycerinated alcohol at $70 \%$. The identification of taxa, except Nematodes, Oligochaeta and Acari was carried out at the family level, using keys and identification guides (Bond-Buckup and Buckup, 1999; 2008; Epler, 1992; 2001; Lopretto and Tell, 1995; Penak, 1978). Due to the high numbers of Chironomidae in the sediment and its importance in the quality in the determination of lentic environments, those organisms were identified to genera and species, using Trivinho-Strixino (2011). Bryozoans (Plumatellidae), present in the samples, were not included in the analysis. The macroinvertebrates were deposited in the scientific collection of the Laboratory of Limnology at the
Center of Agricultural and Biological Sciences from the University of "Caxias do Sul".

\subsection{Relative abundance (\%)}

In order to determine the predominant taxa of Lake Figueira, as well as occasional occurrences, the relative abundance of each taxonomic group in each replica was obtained.

\subsection{Diversity and equitability index}

The diversity of taxa was calculated according to Shannon's index (1948). The advantage of this index is that it takes into account the number of species and the predominant species. The equitability index refers to the distribution pattern of individuals, among species (Schäfer, 1985). It was used together with the determination of diversity to obtain the distribution standard for both the overall macroinvertebrate fauna as well as for Chironomidae taxa.

\subsection{Data analysis}

All data collected were stored in a database system associated with a Geographic Information System (GIS) and the software SPSS 18 was used to analyse data. Nonparametric correlations were made between taxon richness, organic matter content and depth. The correlation between the biotic (number of taxa) and abiotic (organic matter and depth) variables was analyzed using a multivariate classification analysis. Cosine's index was used to interpret the similarity among the different groups of benthic macroinvertebrates and among the Chironomidae taxa at each sampled depth.

The similarity analysis among the different taxa considered the occurrence in three depth zones in Lake Figueira, described by Schäfer et al. (2009): Secchi Transparency Zone $(<3 \mathrm{~m})$, Euphotic Zone (from 3 to $8 \mathrm{~m}$ ) and the Aphotic Zone (> $8 \mathrm{~m}$ ).

\section{Results and Discussion}

Lake Figueira has peculiar ecological characteristics as a result of its morphology and proximity to the ocean. The pronounced asymmetry is the result of dune movement due to the wind, predominantly northeasterly, which reduces the extension of the East coastal zone, which has abrupt margins with no vegetation, whereas in the west, the margin is characterized by shallow waters with abundant aquatic vegetation (Schäfer, 1992). The effect of the lagoon's morphology and its relationship with the distributions of both 
aquatic vegetation and molluscs was demonstrated by Lanzer and Schäfer (1988).

Silva and Henry (2013) also observed marginal lakes are characterised by high biological diversity due to the presence of aquatic macrophytes in their coastal zones, providing habitats for refuge and food for animals. Among the fauna associated with macrophytes, aquatic macroinvertebrates are important because they are an energy source for predators and fish. Silva and Henry (2013) identified 50 taxa of macroinvertebrates, with greater taxon richness for aquatic insects (37 taxa) divided into eight orders, the order Diptera being the most abundant in the two study periods.

Of the 17 taxa found in Lake Figueira, the Chironomidae family was the most abundant with $31.17 \%$ of total abundance, followed by Rissooidea with 26.13\% (Figure 2). Oligochaeta (4.19\%), Tanaidacea (9.29\%), Sphaeromatidae (12.08\%), Dogielinotidae (6.46\%) and Leptoceridae (5.99\%), although having a low relative abundance, were found at all sampling points.

Macroinvertebrate richness was greatest in summer and the lowest in winter (Table 1). A similar result was observed by Cenzano and Würdig (2006) in Lake Itapeva on the North Shore, RS and by Silva (2010) at Lake Peri, Santa Catarina, Brazil. On the other hand, Volkmer-Ribeiro et al. (2006), studying the biodiversity of Lake Casamento and of Butiazais in Tapes, RS, recorded a reduction in the number of taxa during spring although abundance was high, which was found in Lake Figueira for Chironomidae only.

The macrofaunal composition was also similar to those studied by Rodrigues and Hartz (2001) and Würdig et al. (2007) in other lagoons along the South Brazilian Coastal Plain. Marques et al. (1999) also observed predominance of Chironomidae in the lagoons "Carioca" and "da Barra", in Minas Gerais, Brazil, having found only individuals of the Chironomini tribe, belonging to the Chironominae subfamily. In this study, higher number of subfamilies, tribes and genera were observed. Those results were similar to the ones mentioned by Callisto and Esteves (1996), studying Lake Batata in Pará, Brazil.

The Chironomidae family is presented as dominant, both in lotic and lentic environments, due to its tolerance to extreme situations such as hypoxia and its high competitive capacity (Di Giovanni et al., 1996). According to Dévai (1990), the dominance of collector organisms, mainly Chironomidae, is evidence for enrichment by organic matter in the sediment.

The sediment organic matter content and depth were significantly and positively correlated $\left(\mathrm{r}=0.962 ; \mathrm{r}^{2}=0.926\right.$ and $\left.\mathrm{p}<0.001\right)$, having, therefore, higher accumulation of organic matter in the deeper places (Figure 3). Abundance of taxa, on the other hand, was inversely and not significantly related with depth $\left(r=-0.41 ; r^{2}=0.17\right.$; $\mathrm{p}>0.05)$ and organic matter $\left(\mathrm{r}=0.25 ; \mathrm{r}^{2}=0.066\right.$

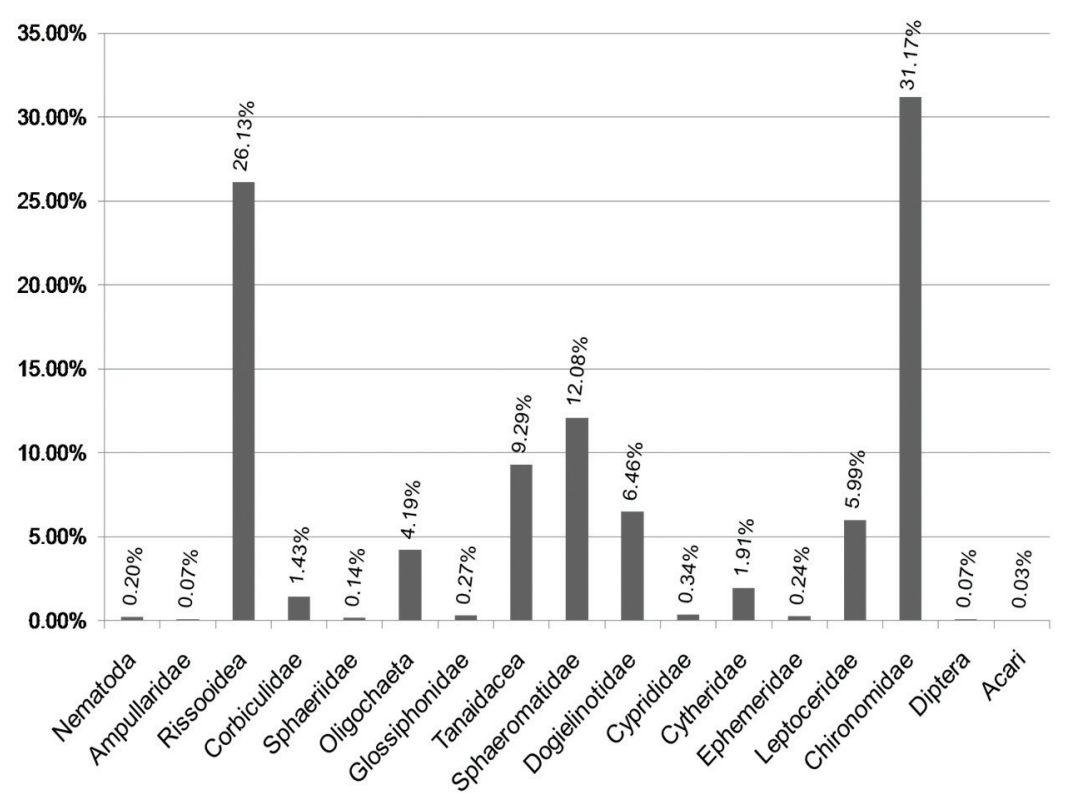

Figure 2. Relative abundance of benthic macroinvertebrate taxa in Lake Figueira in all samples. 
Table 1. Macroinvertebrate taxa of Lake Figueira and their relative abundance (\%) during the entire sampling period and diversity of macroinvertebrates (Hs), maximum diversity (Hmax) and Eveness rate (E).

\begin{tabular}{|c|c|c|c|c|c|c|}
\hline Phylum & $\begin{array}{c}\text { Class/ } \\
\text { Subclass* }\end{array}$ & Family & Summer & Autumm & Winter & Spring \\
\hline \multirow[t]{2}{*}{ Nematoda } & \multirow{3}{*}{ Gastropoda } & & 0.33 & & & \\
\hline & & Ampullariidae & 0.07 & & & \\
\hline \multirow{3}{*}{ Mollusca } & & Rissooidea & 15.51 & 17.45 & 21.16 & 48.60 \\
\hline & \multirow{2}{*}{ Bivalvia } & Corbiculidae & 1.04 & 0.26 & & 7.26 \\
\hline & & Sphaeriidae & & & & 0.56 \\
\hline \multirow{3}{*}{ Annelida } & \multirow{3}{*}{$\begin{array}{l}\text { Oligochaeta } \\
\text { Hirudinea }\end{array}$} & & 4.59 & 0.50 & 10.85 & 1.68 \\
\hline & & Glossiphoniidae & 0.39 & & & 2.51 \\
\hline & & Tanaidacea & 8.61 & 0.61 & 5.22 & 26.82 \\
\hline \multirow{9}{*}{ Arthropoda } & \multirow[t]{2}{*}{ Malacostraca } & Sphaeromatidae & 9.71 & & 10.12 & \\
\hline & & Dogielinotidae & 11.79 & 0.26 & & \\
\hline & \multirow{3}{*}{ Ostracoda } & Cyprididae & 0.15 & 0.50 & 0.31 & 0.28 \\
\hline & & Cytheridae & 3.57 & & & \\
\hline & & Ephemeridae & 0.14 & & & 0.28 \\
\hline & \multirow{3}{*}{ Insecta } & Leptoceridae & 9.06 & 1.81 & 1.78 & 3.63 \\
\hline & & Chironomidae & 33.38 & 78.23 & 50.56 & 8.38 \\
\hline & & Diptera & 1.60 & 0.38 & & \\
\hline & Acrachnida & Acari $^{\star}$ & 0.06 & & & \\
\hline \multicolumn{3}{|c|}{ Diversity of macroinvertebrate taxa $(\mathrm{Hs})$} & 2.55 & 0.66 & 1.41 & 1.49 \\
\hline \multicolumn{3}{|c|}{ Evenness of the taxa $(E)$} & 0.86 & 0.30 & 0.68 & 0.62 \\
\hline
\end{tabular}

* Subclass.

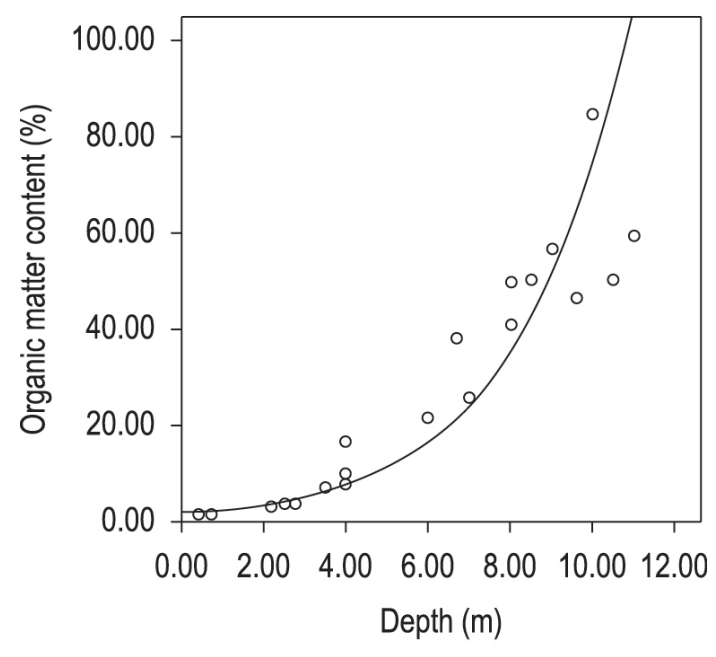

o Observed — Exponential

Figure 3. Relationship between organic matter (\%) and depth $(\mathrm{m})$ in Lake Figueira $\left(\mathrm{y}=1.798 \mathrm{e}^{0.371 \mathrm{x}}\right)$.

e p $>0.05)$. This agrees with the results of Rodrigues (1996) for "Lagoa Caconde", in the North Coast, where there was a close relationship between organic matter and depth, but not between those parameters and the number of taxa and differs from those of Cenzano and Würdig (2006), Anjos et al. (2011) e Lisboa et al. (2011), who found a strong correlation between organic matter and the number of organisms.
The lack of a relationship between taxon richness and organic matter and depth, may be explained by the oxygenation of the entire water column, resulting from the low depth and strong wind action, a peculiarity of these coastal ecosystems that reflects directly on the structure and distribution of the benthic communities (Schäfer et al., 2009). With the oxygenation of water near the sediment, aerobic conditions prevail that enable the survival of several taxa, independently of the depth and amount of organic matter in the sediment. In some coastal lagoons of Rio Grande do Sul algae of the genera Chara and Nitella have been found at depths of up to $10 \mathrm{~m}$, where the low turbidity allows the penetration of light (Schäfer 1992, Albertoni et al., 2001). The permanent movement of the water column also causes the phytoplankton to reach greater depths (Schäfer et al., 2009), enabling the existence of filter feeding organisms such as Corbiculidae (Table 1).

Classification (Figure 4) resulted in the division of the fauna into three large groups, with group A composed of organisms that live in the deeper areas and generalist taxa, such as Chironomidae, Rissooidea, Leptoceridae and Oligochaeta that did not demonstrate any preference for depth. Group $\mathrm{B}$ is composed of organisms inhabiting the Photic Zone, with Ephemeridae and Sphaeromatidae found from 3 to $8 \mathrm{~m}$ and Ampullariidae and Cytheridae 


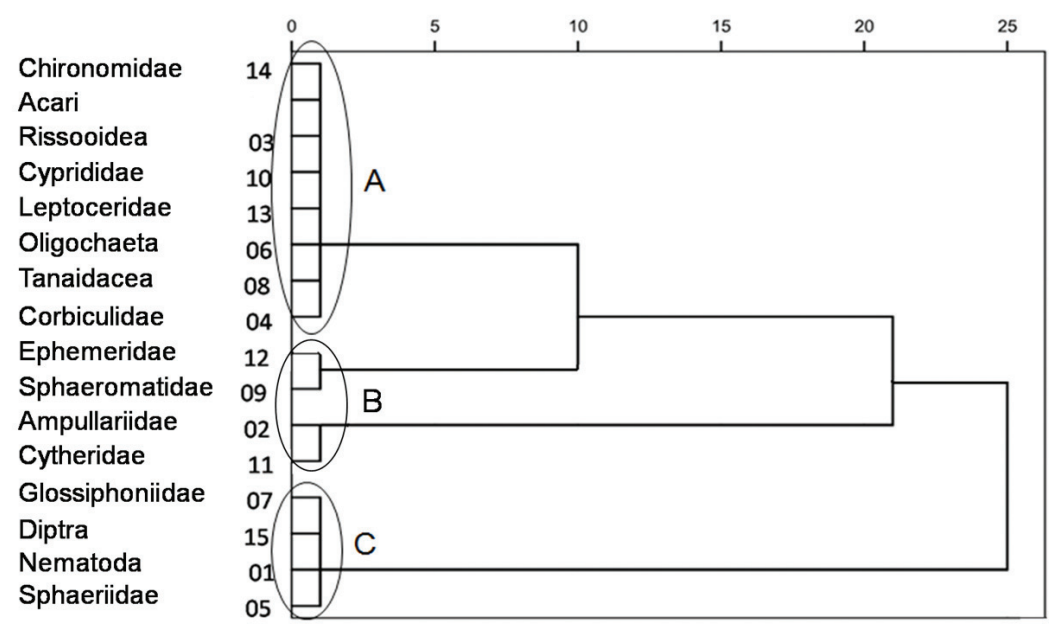

Figure 4. Macroinvertebrate groupings with respect to depth $(\mathrm{m})$ of Lake Figueira, by Cosine's algorithm: (A) below the euphotic zone depths, (B) within the euphotic zone (C) depths under $3 \mathrm{~m}$.

at almost all depths until $8 \mathrm{~m}$. Finally, group C, is made up of the macroinvertebrates inhabiting depths deeper than $3 \mathrm{~m}$, differing from the results of Cenzano and Würdig (2006), at Lake Itapeva in the North Coast, where they observed greater abundance and diversity in marginal regions, and lower diversity in deeper ones, emphasizing that in this lagoon there is a correlation between numbers of individuals and organic matter content, which in Lake Figueira was not significantly correlated with the distribution of taxa.

Equitability was low in all seasons of the year due to the relatively even distribution and higher abundance of the predominant taxa in Lake Figueira, such as Rissooidea, Oligochaeta, Tanaidacea, Leptoceridae and Chironomidae (Table 1).

Chironomidae has been considered an important indicator of water quality in lakes, being increasingly used as bioindicators (Fonseca et al., 2004; Heiri, 2004). The Chironomidae was represented by 30 taxa integrating three subfamilies: Chironominae, Tanypodinae and Orthocladinae. The Chironominae subfamily was more abundant $(95.1 \%)$ with genera pertaining to tribes Chironomini $(81.69 \%)$ and Tanytarsini (13.41\%). The Tanypodinae was composed of individuals of tribes Coelotanypodini (1.04\%), Macropelopini (0.09\%), Pentaneurini (3.59\%) and Procladini $(0.09 \%)$, and the Orthocladinae subfamily was composed by the Orthocladini tribe (0.09\%) (Figure 5).

The presence of Tanypodinae highlights the high oxygenation found by Schäfer et al. (2009), because, as Merritt and Cummins (1996) assert,

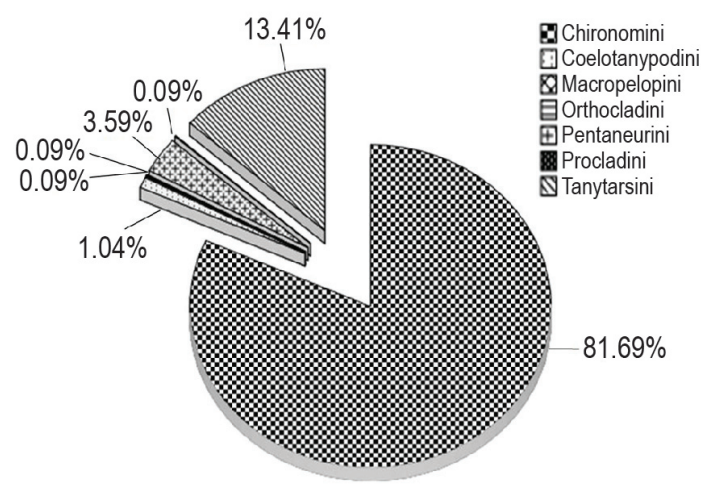

Figure 5. Chironomidae tribes in Lake Figueira found in all collections.

those individuals are found in environments with oxygenation of the whole water column down to the sediment.

There is a greater abundance of Chironomidae taxa in the autumn (19 taxa) and lower diversity in spring ( 6 taxa). Besides a larger number of taxa in autumn, certain genera were predominant only in this season, such as Nilothauma sp.1, Nilothauma sp.2, Polypedilum (Tripodura) sp.1, Polypedilum sp.2, Goeldichironomus xiborena, Dicrotendipes sp.1, Demicryptochironomus sp., Cricotopus sp. 1, Asheum sp., Chironomus gr. salinarius and Parachironomus tirio.

Polypedilum sp. is considered tolerant to organic enrichment (Callisto et al., 1998, Fusari 2006). In the present study, was observed an increase in the amount of chlorophyll- $a$ and soluble reactive phosphorus, may explain the reduction in transparency and consequent change in the trophic 
state of the lagoon, favoring the presence of this species. It is also important to highlight the presence of Chironomus gr. salinarius tolerant to eutrophic environments.

During the winter there was a decrease in the number of taxa, but it was also possible to record the presence of genera characteristic of this season, such as Tanytarsus rhabdomantis, Pentaneura sp. and Genus $X$ (Table 2). Lower numbers of taxa were found in spring. During summer, there was a reappearance of genera found in autumn and winter, Cladopelma forcipis, Caladomyia sp. C, Tanytarsus sp., Brudiniella sp., Labrundinia sp. 2 and Procladius sp. sampled in this season only. Similar results were also observed by Strixino and Trivinho-Strixino (1998), studying different reservoirs in cerrado areas of São Paulo.

Larvae of Procladius sp., according to Voldopichi and Cowell (1984) are favored by high amounts of organic matter in sediment and/or by fine sediments.

Chironomini and Pentaneurin were present during all seasons. The higher richness and variety of taxa during the autumn was due to predominance of Chironomini genera. In autumn, on the other hand, there was low equitability, caused by dominance of some taxa such as Cladopelma forcipis, Cryptochironomus brasiliensis and Aedokritus sp. (Table 2).

Procladini and Macropelopini were recorded only in the summer, whereas Coelotanypodini and Orthocladini appeared in autumn, all with low abundance and represented by a single genera (Table 2).

Tanytarsini was absent in autumn (Table 2), which may be related with the cyanobacterial blooms in this period (Schäfer et al., 2009). The amount of chlorophyll- $a$ in January was $4 \mathrm{mg} / \mathrm{m}^{3}$ and over $100 \mathrm{mg} / \mathrm{m}^{3}$ in April, reducing the water

Table 2. Seasonal distribution of Chironomidae in Lake Figueira, central coast of Rio Grande do Sul.

\begin{tabular}{|c|c|c|c|c|c|c|}
\hline Subfamily & Tribe & Genera & Summer & Autumm & Winter & Spring \\
\hline \multirow[t]{7}{*}{ Tanypodinae } & Coelotanypodini & Coelotanypus sp. & 4.39 & 0.18 & & \\
\hline & Macropelopini & Brundiniella sp. & 0.44 & & & \\
\hline & Pentaneurini & Ablabesmyia (Karelia) 1 & & 0.18 & 0.56 & \\
\hline & & Labrundinia sp. 2 & 0.88 & & & \\
\hline & & Larsia sp. & 9.21 & & 3.37 & 7.23 \\
\hline & & Pentaneura sp. & & & 0.56 & \\
\hline & Procladini & Procladius sp. & 0.44 & & & \\
\hline \multirow[t]{22}{*}{ Chironominae } & Chironomini & Asheum sp. & & 2.28 & & \\
\hline & & Axaurus sp. & 0.44 & 0.35 & & \\
\hline & & Cladopelma forcipis & 3.95 & 43.68 & & \\
\hline & & Cryptochironomus brasiliensis & 0.88 & 11.75 & 6.18 & \\
\hline & & Demicryptochironomus sp. & & 0.88 & & \\
\hline & & Dicrotendipes sp. 1 & & 0.18 & & \\
\hline & & Dicrotendipes sp.3 & 3.95 & 4.39 & & 15.66 \\
\hline & & Goeldichironomus maculatus & & & 4.49 & 1.2 \\
\hline & & Goeldichironomus xiborena & & 2.28 & & \\
\hline & & Chironomus gr. salinarius & & 0.35 & & \\
\hline & & Nilothauma sp.1 & & 6.32 & & \\
\hline & & Nilothauma sp.2 & & 0.53 & & \\
\hline & & Parachironomus tirio & & 0.35 & & \\
\hline & & Polypedilum (Tripodura) sp.1 & & 0.35 & & \\
\hline & & Polypedilum sp.2 & & 0.18 & & \\
\hline & & Xenochironomus sp. & 0.44 & & 26.97 & 59.04 \\
\hline & & Fissimentum sp.2 & 2.63 & 0.18 & & \\
\hline & & Aedokritus sp. & 57.46 & 25.44 & & 4.82 \\
\hline & & Genus X & & & 0.56 & \\
\hline & Tanytarsini & Tanytarsus rhabdomantis & & & 2.25 & \\
\hline & & Caladomyia sp. C & 13.16 & & 55.06 & 12.05 \\
\hline & & Tanytarsus sp. & 1.75 & & & \\
\hline Orthocladiinae & Ortocladini & Cricotopus sp. & & 0.18 & & \\
\hline \multicolumn{3}{|c|}{ Diversity of macroinvertebrate taxa (Hs) } & 1.5 & 1.66 & 1.28 & 1.24 \\
\hline \multicolumn{3}{|c|}{ Evennes of the taxa $(E)$} & 0.57 & 0.01 & 0.58 & 0.69 \\
\hline
\end{tabular}


transparency resulting in a hypertrophic state (Schäfer et al., 2009). According to Deshon (1995), Tanytarsini normally tolerates intermediate levels of pollution, but there is a decrease in the abundance of some genera when exposed to sudden stress levels, such as observed in Lake Figueira. It may also have favored the occurrence of Polypedilum sp. in autumn due to its tolerance to organic enrichment and adverse conditions such as eutrophication (Callisto et al., 1998, Fusari, 2006). The Tanytarsini tribe was more abundant in the winter when the water body returned to the mesotrophic state.

Equitability was low in all seasons due to the dominance of few species belonging to Chironomini and Tanytarsini tribes (Table 1). The number of Chironomidae taxa was inversely related but not significantly, with depth $\left(\mathrm{r}=-0.15 ; \mathrm{r}^{2}=0.02 ; \mathrm{p}\right.$ $>0.05)$ and organic matter content $(r=-0.16$; $\mathrm{r}^{2}=0.03$ and $\mathrm{p}>0.05$ ), as was found for other invertebrates in Lake Figueira.

Many studies have demonstrated the use of Chironomidae in determination of water quality in lakes (Fonseca et al., 2004, Heiri, 2004). The presence or absence of those invertebrates in the sediment was applied by Thienemann $(1925,1931)$ as a classification criterion, differentiating between oligotrophic and eutrophic lakes.

The grouping performed with the same depth parameter using only Chironomidae taxa, shows a marked relationship with seasonality for most of the sampling points where there is predominance of some Chironomidae genera, in eight distribution groups. The results of Lake Figueira can be compared with those of Lucca et al. (2010) at Lake Caçó, Maranhão, Brazil.

In group $A$, taxa predominantly inhabiting depths of 8 meters are found, whereas group B is represented by Nilothauma sp. which is only found at depths of 8 to $11 \mathrm{~m}$. In group C Cladopelma forcipis, Axaurus sp. and Procladius sp. genera are found, which are able to inhabit a greater range of depths from between $2.5 \mathrm{~m}$ and $8 \mathrm{~m}$. Group $\mathrm{D}$ and $\mathrm{E}$ are composed of Chironomidae that had no preference for any depth in particular, being very generalist and thus not useful as bioindicators of organic matter content of the sediment of this ecosystem. In groups $F$ and $G$, only taxa found in summer and winter, respectively, occur, and inhabitants of depth between $1 \mathrm{~m}$ to $9 \mathrm{~m}$. Genus $X$ is isolated in group $\mathrm{H}$ and found only at depths down to $1 \mathrm{~m}$ (Figure 6).

Some genera may be used as indicators of the organic matter content in Lake Figueira since it is strongly correlated with depth $\left(r=0.933 ; r^{2}=0.870\right.$ e $\mathrm{p}<0.001$ ), as mentioned previously.

Whereas Cladopelma forcipis, Axaurus sp. and Procladius sp. are able to inhabit a range of depths between $2.5 \mathrm{~m}$ and $8 \mathrm{~m}$, Nilothauma sp. predominates in sediments with higher organic matter contents and at depths of between $8 \mathrm{~m}$ and $11 \mathrm{~m}$ and Genus $X$ is found only at depths down to $1 \mathrm{~m}$.

Parachironomus tirio
Polypedilum
Demicryptochironomus sp.
Chironomus gr. salinarius
Cricotopus sp.
Nilothauma
Axaurus sp.
Cladopelma forcipis
Procladius sp.
Cryptochironomus brasiliensis
Xenochironomus sp.
Dicrotendipes sp1
Goeldicironomus
Fissimentum sp.
Aedokritus sp.
Chironomidae
Tanytarsus sp.
Larsia sp.
Caelotanypus
Brundiniella
Labrundinia sp2
Tanytarsus rhabdomantis
Pentaneura sp.
Ablabesmyia (Karelia) 1
Genus X

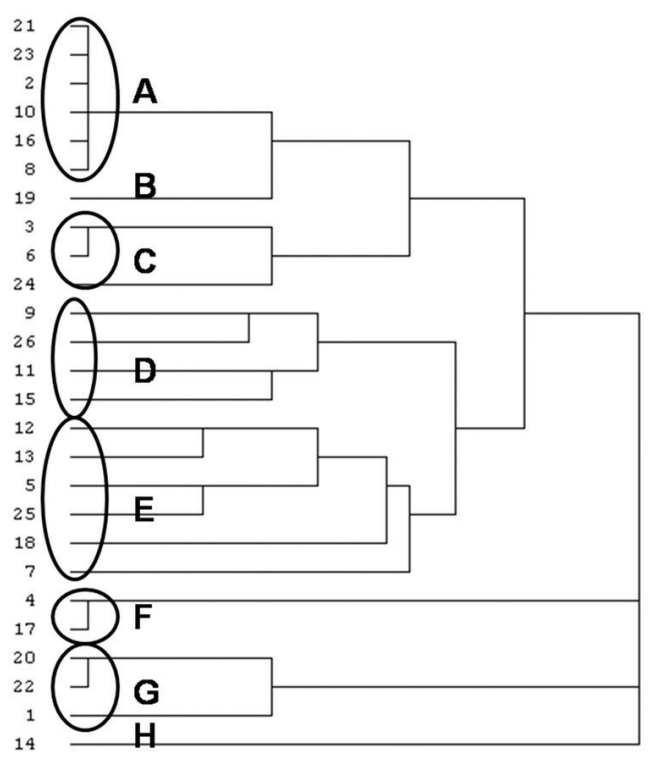

Figure 6. Dendrogram of Chironomidae genera with respect to different depths $(\mathrm{m})$ in Lake Figueira by Cosine's algorithm, (A) genera in depths of at least $8 \mathrm{~m}$, (B) genera between $8 \mathrm{~m}$ and $11 \mathrm{~m},(\mathrm{C})$ genera in depths from 2.5 $\mathrm{m}$ to $8 \mathrm{~m}$, (D) and (E) genra which have no preference for by any depth in particular, (F) and (G) genera in depths from $1 \mathrm{~m}$ to $9 \mathrm{~m}$ respectively. The group $\mathrm{H}$ is composed of Genus $X$ only, which is found in depths of less than $1 \mathrm{~m}$. 
Our results demonstrate that there are potential indicators such as Larsia sp., Goeldichironomus maculatus, Xenochironomus sp. e Caladomyia sp. $C$, Tanytarsus sp. and Tanytarsus rhabdomantis, which were absent in autumn, perhaps due to their sensitivity to highly enriched conditions at that time. Aedokritus sp., Cladopelma forcipis, Cryptochironomus brasiliensis and Nilothauma sp., on the other hand, were abundant and demonstrated tolerance to the hypertrophy found in the lagoon, besides Chironomus gr. salinarius already identified as an indicator of eutrophic environments.

Similar results were found by TrivinhoStrixino et al. (1999) on Lake Infernão, São Paulo, who reported that Asheum, Beardius, Chironomus, Goeldichironomus, Parachironomus, Polypedilum and were the most abundant genera of Chironomidae. These are less abundant in the present study, being related to eutrophication of Lake Figueira in the fall. The dominance of macroinvertebrate collectors indicates the prevalence of a detritivore chain in the macrophytes, and, as pointed out by Mastrantuono (1986), this could be an indication of trophic enrichment of the lake, already detected in Lake Infernão by the invasion of Scirpus cubensis (macrophytes) that in recent years has occupied the greater part of the lake. It is assumed that this invasion will result in the decrease or disappearance of other macrophytes, and consequently, will change the whole macroinvertebrate assemblage structure.

The results suggest that chironomid composition constitutes an important tool for predicting the trophic conditions of lakes and may be a useful tool for monitoring water quality in other lakes in the region.

\section{Conclusion}

The fauna of Lake Figueira is highly related with seasonality but the abundance of taxa is not correlated with organic matter content and depth, whereas both these abiotic factors are highly correlated. This is probably due to the frequent high level of oxygenation of the entire water column, unusual for non-polymictic lagoons. Eleven species may be useful for the biological monitoring of Lake Figueira: Larsia sp., Goeldichironomus maculatus, Xenochironomus sp., Aedokritus sp., Cladopelma forcipis, Cryptochironomus brasiliensis, Nilothauma sp.1, Caladomyia sp. C, Tanytarsus sp., Tanytarsus rhabdomantis, and Chironomus gr. salinarius because their tolerance of eutrophic environments makes them suitable as indicators of the trophic state of this lentic ecosystem.

\section{References}

ABÍliO, FJP., RUFFFO, TLM., SOUZA, AHFS., FLORENTINO, HS., OLIVEIRA JUNIOR, ET., MEIRELES, BN. and SANTANA, ACD. 2007. Macroinvertebrados aquáticos como bioindicadores de qualidade ambiental de corpos aquáticos da caatinga. Oecolologia Brasiliensis, vol. 11, p. 397-409. http://dx.doi.org/10.4257/oeco.2007.1103.09

ALBERTONI, EF., PALMA-SILVA, C. and ESTEVES, FA. 2001. Macroinvertebrates associated with Chara in a tropical coastal lagoon (Imboassica lagoon, Rio de Janeiro, Brazil). Hydrobiologia, vol. 457, p. 215224. http://dx.doi.org/10.1023/A:1012233818709

ANJOS, AF., TAKEDA, AM. and PINHA, GD. 2011. Distribuição espacial e temporal das larvas de Chironomidae em diferentes ambientes do complexo - rio Baía, Estado do Mato Grosso do Sul, Brasil. Acta Scientiarum. Biological Sciences, vol. 33, no. 4, p. 417-426.

BARTON, DR. and METCALFE-SMITH, JL. 1992. A comparison of sampling techniques and summary indices for assessment of water quality in the Yamaska River, Quebec, based on benthic macroinvertebrates. Environmental Monitoring and Assessment, vol. 21, p. 225-244. PMid:24234488. http://dx.doi. org/10.1007/BF00399689

BENKE, AC. 1984. Secondary production of aquatic insects. In RESH, VH. and ROSEMBERG, DM., eds. The ecology of aquatic insects. Praeger Publishers. p. 289-322.

BOND-BUCKUP, G. and BUCKUP, L. 1999. Os crustáceos do Rio Grande do Sul. Porto Alegre: Editora da Universidade Federal do Rio Grande do Sul. $503 \mathrm{p}$.

BOND-BUCKUP, G. and BUCKUP, L., orgs. 2008. Biodiversidade dos Campos de Cima da Serra. Porto Alegre: Libretos. 196 p.

CAIRNS JUNIOR, J. and PRATT, JR. 1993. A history of biological monitoring using benthic macroinvertebrates. In ROSEMBERG, DM. and RESH, VH., eds. Freshwater Biomonitoring and Benthic Macroinvertebrates. New York: Chapman \& Hall. p. 11-27.

CAllisto, M. and ESTEVES, F. 1996. A Macroinvertebrados bentônicos em dois Lagos Amazônicos: Lago Batata (um ecossistema impactado por rejeito de bauxita) e Lago Mussurá (Brasil). Acta Limnologica Brasiliensia, vol. 8, p. 137-147.

CALLISTO, M., FONSECA, J. and GONCALVES, J. 1998. Benthic macroinvertebrate community structure in an Amazonian lake impacted by bauxite tailing (Pará, Brazil). Proceedings of the International 
Association of Theoretical and Applied Limnology, vol. 26, p. 2053-2055.

CENZANO, CSS. and WÜRDIG, NL. 2006. Spatial and temporal variations of the benthic macrofauna in different habitats of a lagoon of the northern coastal system of Rio Grande do Sul State, Brazil. Acta Limnologica Brasiliensia, vol. 18, no. 2, p. 153-163.

DESHON, JE. 1995. Development and application of the invertebrate community index (ICI). In DAVIS, WS., SIMON, TP., eds. Biological Assessment and Criteria: Tools for Water Resource Planning and Decision Making. Boca Raton: Lewis Publishers, p. 217-243.

DÉVAI, G. 1990. Ecological background and importance of the change of chironomid fauna in shallow Lake Balaton. Hydrobiologia, vol. 191, p. 189-198. http:// dx.doi.org/10.1007/BF00026052

DI GIOVANNI, MV., GORETTI, E. and TAMANTI, V. 1996. Macrobenthos in Montedoglio Reservoir, central Italy. Hydrobiologia, vol. 321, p. 17-28. http:// dx.doi.org/10.1007/BF00018673

EPLER, JH. 1992. Byosistematics of the genus Dicrotendipes Kieffer, 1913 (Díptera: Chironomidae) of the world. American Entomological Society, vol. 36, p. 1-21.

EPLER, JH. 2001. Identification Manual for the Larvae Chironomidae (Diptera) of North and South Carolina: A guide to the taxonomy of the midges of the southeastern United States, including Florida. Special Publication. North Carolina: Johns river Water Management District. 526 p. Disponível em: <http: //www.esb. ener.state.nc.us/BAUwww/Chironomid.htm>. Accesso em: 15 mar. 2009.

FONSECA, J., ESTEVES, F. and CALLISTO, M. 2004. Distribution of Chironomidae larvae in an Amazonian flood-plain lake impacted bauxite tailings (Brazil). Amazoniana, vol. 18, no. 1-2, p. 109-123.

FUSARI, ML. 2006. Estudo das Comunidades de Macroinvertebrados Bentônicos das Represas do Monjolinho e do Fazzari no Campus da UFSCar, Município de São Carlos, SP. São Carlos: Universidade Federal de São Carlos. 80 p. [Dissertação de mestrado].

GARCIA-CRIADO, F., BECARES, E. and FERNANDES-ALAEZ, M. 2005. Plant-associated invertebrates and ecological quality in some Mediterranean shallow lakes: Implications for the aplication of the E.C. Water Framework Directive. Aquatic Conservation: Marine and Freswater Ecossystems, vol. 15, p. 31-50. http://dx.doi. org/10.1002/aqc.641

GUERESCHI, RM. and MELÃO, MGG. 1997. Monitoramento Biológico da Bacia hidrográfica do Rio Monjolinho pelo uso de Macroinvertebrados
Bentônicos. In Anais do VII Seminário de Ecologia, 1997. São Carlos: EdUFSCar. p. 61-76.

HEIRI, O. 2004. Within-lake variability of subfossil chironomid assemblages in shallow Norwegian lakes. Journal of Paleolimnology, vol. 32, p. 67-84. http:// dx.doi.org/10.1023/B:JOPL.0000025289.30038.e9

J OHNSON, RK., WIEDERHOLM, T. and ROSEMBERG, DM. 1993. Freshwater biomonitoring using individual organisms, populations, and species assemblages of benthic macroinvertebrates. In ROSEMBERG, DM. and RESH, VH., eds. Freshwater biomonitoring and benthic macroinvertebrates. New York: Chapman \& Hall. p. 40-158.

KOTTEK, M., GRIESER, J., BECK, C., RUDOLF, B. and RUBEL, F. 2006. World map of the KöppenGeiger climate classifcation updated. Meteorologische Zeitschrift, vol. 15, p. 259-263. http://dx.doi. org/10.1127/0941-2948/2006/0130

KRULL, JN. 1970. Aquatic plant-macroinvertebrate associations and waterfowl. Journal of Wildlife Management, vol. 3, no. 34, p. 707-718.

LANZER, RM., SCHÄFER, A. 1985. Padrôes de distribuição de moluscos dulceaquícolas nas lagoas costeiras do Sul do Brasil. Revista Brasileira de Biologia, vol. 45, no. 4, p. 535-545.

LANZER, RM. and SCHÄFER, A. 1987. Moluscos dulceaquícolas como indicadores de condições tróficas em lagoas costeiras do Sul do Brasil. Revista Brasileira de Biologia, vol. 47, no. 1-2, p. 47-56.

LANZER, RM. and SCHÄFER, A. 1988. Fatores determinantes da distribuiçấo de moluscos dulceaquícolas nas lagoas costeiras do Rio Grande do Sul. Acta Limnologica Brasiliensia, vol. 11, p. 649675.

LISBOA, LK., SILVA, ALL. and PETRUCIO, MM. 2011. Aquatic invertebrate's distribution in a freshwater coastal lagoon of southern Brazil in relation to water and sediment characteristics. Acta Limnologica Brasiliensia, vol. 23, no. 2, p. 119-127. http://dx.doi.org/10.1590/S2179$975 \times 2011000200002$

LOPRETTO, EC. and TELL, G. 1995. Ecossistemas de águas continentals: metodologias para su estúdio. La Plata: Ediciones Sur. v. 3, 1401 p.

LUCCA, JV., PAMPLIN, PAZ., GESSNER, AF., TRIVINHO-STRIXINO, S., SPADANALBUQUERQUE, AL. and ROCHA, O. 2010. Benthic macroinvertebrates of a tropical lake: Lake Caçó, MA, Brazil. Brazilian Journal of Biology, vol. 70, no. 3, p. 593-600. PMid:20730346. http:// dx.doi.org/10.1590/S1519-69842010000300016 
MARQUES, MGSM., FERREIRA, RL. and BARBOSA, FARA. 1999. Comunidade de Macroinvertebrados aquáticos e características Limnológicas das lagoas Carioca e da Barra, Parque estadual do Rio Doce, MG. Revista Brasileira de Biologia, vol. 59, no. 2, p. 203-210. http://dx.doi.org/10.1590/S003471081999000200004

MERRITT, RW. and CUMMINS, KW. 1996. An Introduction to the Aquatic insect of North America. 3rd ed. Kendall-Hunt. 862 p.

MERRITT, RW., CUMMINS, KW. and ANDRADE, PCN. 2005. The use of invertebrate functional groups to characterize ecosystem attributes in selected streams and rivers in southeast Brazil. Studies on Neotropical Fauna and Environment, vol. 40, no. 1, p. 71-90.

MASTRANTUONO, L. 1986. Community structure of zoobenthos associated with submerged macrophytes in the eutrophic Lake Nemi (Central Italy). Bolletino di zoologia, vol. 53, p. 41-47.

PENAK, RW. 1978. Fresh-Water invertebrates of the United States. 2nd ed. John Wiley \& Sons. 803 p.

RESH, VH and JACKSON, JK. 1993. Rapid assessment Approach to Biomonitoring Using Benthic Macroinvertebrates. In ROSENBERG, DM. and RESH, VH., eds. Freshwater biomonitoring and benthic macroinvertebrates. New York: Chapman \& Hall. p. 159-194.

RODRIGUES, GG. 1996. Caracterização Dinâmicoestrutural da macrofauna bentônica da Lagoa Caconde, Osório, RS. Osório: Universidade Federal do Rio Grande do Sul. 210 p. [Dissertaçáo de mestrado].

RODRIGUES, G. and HARTZ, SM. 2001. Food dynamics of fish and the interaction with macroinvertebrates from a shallow lake in Southern Brazil. Verhandlungen dês Internationalen Verein Limnologie, vol. 27, p. 3309-3314.

ROSSATO, M. and PINHEIRO, Jr., C. 2009. Aspectos socioeconômicos dos municípios de Mostardas, Tavares, São José do Norte e Santa Vitória do Palmar. In SCHÄFER, A., MARCHETTO, C. and BIANCHI, A., eds. Manual de recursos hídricos dos municípios de Mostardas, Tavares, São José do Norte e Santa Vitória do Palmar. Caxias do Sul: EdUCS. p.142-157.

ROSENBERG, DM. and RESH, VH. 1993. Freshwater Biomonitoring and benthic macroinvertebrates. NewYork: Chapman \& Hall. 488 p.

SCHÄFER, A. 1985. Fundamentos de ecologia e biogeografia das águas continentais. Porto Alegre: UFRGS. $532 \mathrm{p}$.

SCHÄFER, A. 1992. Die Küstenseen Südbrasiliens: ein Beitrag zur biogeographischen Raumanalyse der
Restinga. Frans Steiner Verlag, Stuttgart: Steiner. $203 \mathrm{p}$.

SCHÄFER, A., LANZER, R. and STREHER, AS. 2009. Características ecológicas das lagoas costeiras. In SCHÄFER, A., LANZER, R. and PEREIRA, R., eds. Atlas Socioambiental dos municipios de Mostardas, Tavares, São José do Norte e Santa Vitória do Palmar. Caxias do Sul: EDUCS, p. 142-157.

SCHWARZBOLD, A. and SCHÄFER, A. 1984. Gênese e morfologia das lagoas costeiras do Rio Grande do Sul-Brasil. Amazoniana, vol. IX, no. 1, p. 87-104.

SHANNON, CE. 1948. A mathematical theory of communication. Bell System Technical Journal, vol. 27, p. 379-423. http://dx.doi. org/10.1002/j.1538-7305.1948.tb01338.x

SILVA, ALL. 2010. Diversidade e variação espaço-temporal da comunidade de macroinvertebrados bentônicos em uma Lagoa Costeira Subtropical no Sul do Brasil. Florianópolis: Universidade Federal de Santa Catarina. 87 p. [Dissertação de Mestrado].

SILVA, CV. and HENRY, R. 2013. Aquatic macroinvertebrates associated with Eichhornia azurea (Swartz) Kunth and relationships with abiotic factors in marginal lentic ecosystems (São Paulo, Brazil). Brazilian Journal of Biology, vol. 73, no. 1, p. 149162. PMid:23644797. http://dx.doi.org/10.1590/ S1519-69842013000100016

STRIXINO, G. and TRIVINHO-STRIXINO, S. 1998. Povoamento de Chironomidae (Diptera) em lagos artificiais. In NESSIMIAN, JL. and CARVALHO, AL., eds. Ecologia de Insetos Aquáticos. Séries Oecologia Brasiliensis, vol.1. Rio de Janeiro: PPGEUFRJ. p. 141-154.

THIENEMANN, A. 1925. Die Binnengewässer Mitteleuropas Eine limnologische Einführung. Binnengew, vol. 1, p. 1-225.

THIENEMANN, A. 1931. Der Produktionsbegriff in der Biologie. Archv für Hydrobiologie, vol. 22, p. 616- 622.

TOMAZELLI, LJ. and VILLWOCK, JA. 2005. Mapeamento geológico de planícies costeiras: o exemplo da costa do Rio Grande do Sul. Gravel, vol. 3, p. 109-115.

TRIVINHO-STRIXINO, S., CORREIA, LCS., SONODA, K. 1999. Phytophilous Chironomidae (Diptera) and other Macroinvertebrates in the Ox-Bow Infernão Lake (Jataí Ecological Station, luiz Antônio, SP, Brazil). Revista Brasileira de Biologia, vol. 60, no. 3, p. 527-535. http://dx.doi. org/10.1590/S0034-71082000000300018

TRIVINHO-STRIXINO, S. 2011. Larvas de Chironomidae. Guia de identificação. São Carlos: 
Depto. Hidrobiologia, Lab. Entomologia Aquática, UFSCAR. 371 p.

VOLDOPICH, DS., COWELL, BC. 1984. Interaction of factors governing the distribution of a predatory aquatic insect. Ecology, vol. 65, no. 1, p. 39-52. http:// dx.doi.org/10.2307/1939456

VOLKMER-RIBEIRO, C., ROSA-BARBOSA, RD., GUADAGNIN, DL., MOSTARDEIRO, CC. and PEDROSO, APS. 2006. Macroinvertebrados bentônicos. In BECKER, FG., RAMOS RA., and MOURA, LDA., eds. Biodiversidade, Regiöes da Lagoa do Casamento e dos Butiazais de Tapes, Planície Costeira do Rio Grande do Sul / Ministério do Meio Ambiente. Brasília: MMA/ SBF. p. 156-163.
WARD, JV. 1992. Aquatic insect ecology. In Biology and habitat. New York: John Wiley \& Sons. 438 p.

WETZEL, RG. 2001. Limnology, Lake and river ecosystems. 3rd ed. San Diego: Academic Press. $1006 \mathrm{p}$.

WIEDERHOLM, T. 1980. Use of benthos in lake monitoring. Journal of the Water Pollution Control Federation, vol. 52, p. 537-547.

WÜRDIG, NL., CENZANO, CSS. and MOTTA MARQUES, D. 2007. Macroinvertebrate communities structure in different environments of the Taim Hydrological System in the state of Rio Grande do Sul, Brazil. Acta Limnologica Brasiliensia, vol. 19, no. 4, p. 427-438.

Received: 25 March 2012 Accepted: 18 December 2013 